\begin{tabular}{|lll|}
\hline Diterima & $:$ & 17 Desember 2020 \\
Direvisi & $:$ & 31 Maret 2021 \\
Disetujui & $:$ & 30 Juni 2021 \\
Diterbitkan & $:$ & 30 Juni 2021 \\
\hline
\end{tabular}

\title{
PROFIL KEMAMPUAN COMPUTATIONAL THINKING ANAK USIA 5-6 TAHUN
}

\author{
Rosyida Ani Dwi Kumala1, Upik Elok Endang Rasmani² \& \\ Nurul Kusuma Dewi ${ }^{3}$ \\ email: rosyidaanidwikumala@gmail.com', upikelok@staff.uns.ac.id², \\ kusuma.dewi@staff.uns.ac.id ${ }^{3}$ \\ Pendidikan Guru Pendidikan Anak Usia Dini, Universitas Sebelas Maret \\ Jalan Slamet Riyadi No.449, Pajang, Kec. Laweyan, Kota Surakarta, \\ Jawa Tengah 57146, Indonesia
}

\begin{abstract}
Abstrak: Kemampuan computational thinking sudah dipertimbangkan untuk diberikan kepada anak sejak usia dini. Namun belum banyak gambaran terkait kemampuan ini. Penelitian ini bertujuan melaporkan profil kemampuan computational thinking anak usia 5-6 tahun di sebuah PAUD di Kota Surakarta. Penelitian ini merupakan penelitian kualitatif. Teknik pengumpulan data yaitu wawancara pada kepala sekolah, wakil kepala sekolah bidang kurikulum, observasi pembelajaran sebanyak 36 kali, dan dokumentasi. Teknik analisis data melalui proses penyajian data, reduksi data, dan penarikan kesimpulan. Hasil penelitian melaporkan bahwa ada delapan kemampuan computational thinking yang paling terlihat. Kemampuan tersebut adalah: 1) anak terbiasa dengan kegiatan berinstruksi; 2). anak terlatih untuk mencari solusi dari permasalahan yang dihadapi; 3) anak terbiasa mengungkapkan ide berupa gagasan, pendapat, atau karya; 4) anak mampu membagi tugas secara mandiri maupun dengan diskusi teman sebaya; 5) anak terbiasa dengan ice breaking dengan menerjemahan kode; 6) anak sudah terbiasa mengoperasikan komputer secara individu, 7) anak mengetahui fungsi dari fitur colour dan shape yang terdapat pada aplikasi power point dan paint; dan 8) anak mampu menerapkan solusi kedalam permasalahan yang sama pada kegiatan yang memiliki kemiripan dalam penyelesaian. Penelitian ini menyimpulkan bahwa kemampuan computational thinking anak berkembang secara beragam sesuai dengan tingkat intensitas pemberian stimulus.
\end{abstract}

Kata-kata Kunci: anak usia dini, computational thinking, profil, usia 5-6 tahun

\section{THE PROFILE OF COMPUTATIONAL THINKING ABILITY OF CHILDREN AGED 5-6}

\begin{abstract}
Computational thinking skills are important for children from an early age. However, there are not many information related to this ability. This study aims to report the profile of the computational thinking ability of children aged 5-6 years in an early childhood education center in Surakarta City. This research is a qualitative approach with interviews to the headmaster and teacher, observation, and documentation as data collection methods. The data were analyzed through display, reduction, and concluding. The results of the study report that there are eight most visible computational thinking abilities. These children's abilities are 1) accustomed to instructional activities; 2). find solutions when facing some problems; 3) accustomed to expressing ideas in the form of opinions or works; 4) divide tasks independently or peer discussion; 5) familiar with ice breaking by translating codes; 6) accustomed to operating computers individually, 7) know the function of the color and shape features found in Powerpoint
\end{abstract}


and paint applications; and 8) apply solutions to the same problem in activities that have similarities in completion. This study concludes that children's computational thinking abilities develop in various ways according to the intensity level of the stimulus.

Keywords: early childhood, computational thinking stimulation, the profile, children aged 5-6

\section{PENDAHULUAN}

Anak usia dini mengalami proses pertumbuhan dan perkembangan dengan sangat pesat dalam berbagai aspek perkembangan. Terdapat 6 aspek perkembangan anak usia dini yaitu : kognitif, sosialemosional, nilai agama dan moral, bahasa, seni, dan fisik-motorik (Depdiknas, 2014). Charsleswort (dalam Beaty, 2013) mengungkapkan bahwa anak usia dini merupakan periode saat anak-anak aktif membangun pengetahuan baru berupa konsep-konsep dasar yang nantinya akan menjadi fondasi dalam pengetahuan anak. Konsep dasar tersebut dibangun dengan mengeksplorasi dan mempelajari segala sesuatu yang ada disekitar anak dengan pendampingan orang dewasa sebagai penguat pengetahuan anak.

Abad 21 merupakan abad digital atau teknologi dengan semakin meningkatnya kecanggihan teknologi. Sadar atau tidak sadar anak-anak menggunakan ponsel atau perangkat lain sebagai kegiatan konsumsi teknologi. Oleh karena itu, para peneliti mengupayakan agar anak tidak hanya mengkonsumsi media melainkan perlu memberikan kegiatan positif (Ching, Hsu, \& Baldwin, 2018). Mengingat kenyataan ini, muncul program-program yang berfokus pada STEM, coding, dan computational thinking di dalam dunia pendidikan (Bers, Gonzalez, \& Torres, 2019).

Computational thinking (CT) adalah kemampuan yang menggunakan ilmu komputer untuk menyelesaikan dan memecahkan suatu masalah (Bers dkk., 2019). Pendapat tersebut diperkuat oleh Wing dalam Ching dkk. (2018) yang menyatakan bahwa CT mengacu pada seperangkat keterampilan berpikir, proses, dan pendekatan pemecahan masalah yang kompleks dengan menggambarkan konsep dari ilmu komputer. Ilmu-ilmu dasar komputer tersebut berupa algoritma, debugging, proses desain, modularitas, representasi, hardware, software, dan struktur kontrol (Bers, 2018). Meskipun konsep dasar yang terdapat pada computational thinking merupakan ilmu komputer, namun hal tersebut dapat diterapkan ke dalam sejumlah konteks pemecahan masalah.

Rose, Habgood, \& Jay (2017), mengungkapkan bahwa algoritma merupakan serangkaian langkah instruksional yang disusun secara urut untuk memecahkan masalah atau mencapai tujuan akhir.
Pada algoritma yang ditekankan adalah pengerjaan langkah secara urut. Apabila langkah dikerjakan secara acak atau terdapat urutan yang terlewat, maka pencapaian tujuan tidak akan berjalan secara maksimal.

Debugging adalah analisis dan evaluasi dengan menggunakan keterampilan menguji, menelusuri, dan berfikir logis untuk memprediksi dan memverifikasi hasil (Csizmadia dkk., 2015). Pendapat lain diungkapkan oleh (Bers, 2018) bahwa debugging adalah proses pemecahan masalah melalui analisis dan evaluasi sistematis, serta melalui pengembangan strategi pemecahan masalah. Prosesnya bersifat terbuka karena suatu masalah mungkin memiliki banyak solusi. Proses debugging memiliki ciri yakni dalam proses pengujian, seseorang perlu mengkoreksi halhal yang dianggap salah selama proses pemecahan masalah sehingga dapat diperbaiki agar dalam proses pemecahan masalah tersebut dapat berjalan sesuai rencana.

Proses desain melibatkan beberapa langkah yaitu bertanya, membayangkan, merencanakan, membuat, menguji, meningkatkan dan berbagi. Desain proses menuntut seseorang untuk memahami bahwa menciptakan suatu produk yang bertujuan untuk dibagikan kepada orang lain membutuhkan beberapa langkah pekerjaan dan terkadang memerlukan revisi (Strawhacker \& Bers, 2018). Oleh karena itu, proses desain membutuhkan kemampuan pemecahan masalah, ketekunan, dan beberapa kali revisi (Relkin, 2018). Sehingga produk sudah sedikit atau bahkan sama sekali tidak ada kecacatan ketika produk tersebut dibagikan kepada orang lain.

Modularitas adalah pemecahan tugas atau prosedur menjadi unit yang lebih sederhana dan dapat dikelola ataupun digabungkan serta digunakan kembali pada penciptaan proses yang lebih kompleks (Strawhacker \& Bers, 2018). Untuk memecahkan sebuah tugas yang besar, perlu untuk memecahkan tugas tersebut menjadi bagian-bagian kecil untuk mempermudah mengelola permasalahan selama proses pengerjaanya.

Bahasa yang digunakan oleh manusia tentunya tidak sama dengan bahasa yang digunakan oleh mesin. 
Komputer dalam keberjalanannya membutuhkan perintah yang dikirimkan kepada sistem. Oleh karena itu perlu adanya pengubahan bahasa yang biasa digunakan manusia menuju bahasa yang dimengerti oleh komputer. Perintah tersebut berupa bahasa yang dimengerti oleh komputer. Bahasa komputer biasanya berbentuk kode-kode atau simbol tertentu yang merepresentasikan sebuah instruksi berupa algoritma (Suprapto dkk., 2008).

Sistem komputer memerlukan perangkat keras dan lunak untuk beroperasi. Perangkat keras merupakan segala bagian dari sistem komputer atau yang sejenis yang dapat dilihat atau dirasakan oleh panca indera. Seperti monitor, CPU, mouse, keyboard, printer, sound, dan sebagainya.

Sedangkan perangkat lunak merupakan segala sistem yang ada didalam perangkat keras. Perangkat lunak menyediakan instruksi ke perangkat keras dan bekerja bersama sebagai sistem untuk menyelesaikan tugas (Bers, 2018). Penguasaan hardware dan software membutuhkan pemahaman untuk mengetahui fungsi dari berbagai komponen, serta interaksi antara instruksi (kode) dan objek yang menerima instruksi.

Pada ilmu komputer, terdapat berbagai jenis struktur kontrol. kemampuan ini melibatkan kemampuan logika matematika. Terdapat 3 jenis struktur kontrol dasar yaitu perulangan, sebab akibat, dan prasyarat. Memahami struktur kontrol membutuhkan pemahaman tentang pola dan konsep pengambilan keputusan berdasarkan kondisi tertentu serta sebab dan akibat (Bers, 2018).

Akademik dan ilmiah mengakui bahwa CT penting untuk dikembangkan bersamaan dengan membaca dan menulis, yang dibutuhkan pada abad ke-21 (Papadakis, Kalogiannakis, \& Zaranis, 2016). Anak-anak perlu akrab dengan CT karena ini menjadi bagian penting dalam kehidupan anak pada era digital. CT dapat membantu anak untuk memecahkan masalah dengan cara yang berbeda yakni dengan menggunakan konsep komputasi. Penting untuk anak belajar cara menggunakan dan mengembangkan teknologi digital sebagai bekal untuk berpartisipasi penuh ke dalam dunia digital (Chioccariello dkk., 2016). Dengan mempelajari kemampuan ini diharapkan anak dapat mudah beradaptasi dengan perkembangan teknologi yang ada. Sehingga di masa yang akan datang anak tidak hanya mengonsumsi teknologi melainkan dapat menciptakan atau mengembangkan teknologi.

Memperkenalkan CT juga menjembatani kesenjangan antara kurikulum yang ada dengan kebutuhan peserta didik serta masyarakat pada umumnya. Hal tersebut mengingat semakin pesatnya kemajuan teknologi sedangkan kemampuan untuk menguasai teknologi belum ada dalam kurikulum. CT penting untuk memperkuat dunia digital, pemecahan masalah, merancang sistem, serta memahami potensi kecerdasan manusia dan mesin (Papadakis dkk., 2016).

Penelitian sebelumnya telah menunjukkan bahwa anak usia 4 tahun mulai dapat diberikan kemampuan computational thinking (Sullivan, Bers, \& Mihm, 2017). Penelitian lain dilakukan oleh (Ehsan \& Cardella, 2017; Ehsan, Dandridge, Yeter, \& Cardella, 2018) menunjukkan bahwa anak usia 5 tahun ke atas dapat terlibat dan menerapkan berbagai aktivitas CT seperti abstraksi, algoritma, serta debugging dengan dukungan dari orang dewasa.

Peneliti mengkaji kemampuan CT anak dengan mengacu pada indikator hasil adaptasi dari (Rose dkk., 2017), (Bers, 2018), (Relkin, 2018), dan diperkuat oleh (Computer Science Teachers Association, 2017) dengan rincian sebagai berikut :

1. Mampu mengikuti langkah (step by step) secara urut sesuai perintah yang diberikan (Algoritma),

2. Memahami kesalahan yang terjadi pada pengerjaan kegiatan dan mampu memperbaikinya (Debugging),

3. Mampu menuangkan idenya ke dalam sebuah proyek (proses desain),

4. Mampu memecahkan masalah/tugas menjadi bagian kecil (modularitas),

5. Menunjukkan perilaku mampu memahami simbol/ kode yang diberikan (Representasi),

6. Menggunakan CPU, monitor, keyboard, dan mouse sesuai fungsinya (hardware),

7. Mampu mengoperasikan fitur yang ada dalam aplikasi yang digunakan (Software),

8. Melakukan pengulangan tindakan dalam mengerjakan kegiatan yang sama (Struktur kontrol).

Kemampuan CT dapat dikembangkan dengan atau tanpa menggunakan alat pemograman (Zhang \& Nouri, 2019). Lebih rinci, tinjauan literatur yang dilakukan (Ching dkk., 2018) menunjukkan bahwa kemampuan CT pada tingkat pra-TK hingga tingkat sekolah dasar dapat distimulasi dengan menggunakan programming toys, robot kits, board games, augmented reality tools, aplikasi, game, dan berbagai kegiatan dengan konsep komputer.

Berbagai negara di Eropa dan negara diluar 
Eropa seperti Australia, Singapura, dan Malaysia telah menetapkan kebijakan untuk memasukkan CT ke dalam kurikulum pendidikan mereka (Bers, Gonzalez, \& Torres., 2019; Bers, 2018). Di Indonesia, Menteri Pendidikan dan kebudayaan, Nadiem Makarem, juga telah mengeluarkan kebijakan baru terkait kemampuan yang perlu dikembangkan pada pembelajaran era digital salah satunya yaitu CT (Budiansyah, 2020). Oleh karena itu, perlu mempelajari dan mendalami lebih lanjut terkait kemampuan ini.

Berdasarkan uraian yang dipaparkan tentang kemampuan CT, maka perlu untuk mendalami lebih lanjut terkait kemampuan ini terutama pada anak usia dini. Jadi pendidik maupun orang tua dapat mempelajari lebih dalam terkait kemampuan CT.

Berdasarkan hasil observasi awal ditemukan bahwa pembelajaran di salah sebuah PAUD di Kota Surakarta yang menjadi lokasi penelitian ini menggunakan taman. Taman merupakan modifikasi dari sentra dengan perbedaan yang terletak pada pemilihan tema berdasarkan Al-Qur'an dan Hadits. Peneliti mengamati berbagai kegiatan di taman dan ditemukan bahwa beberapa kegiatan menstimulasi kemampuan CT. Selain itu, pada PAUD ini terdapat sarana pembelajaran teknologi berupa komputer yang terdapat pada taman multimedia. Pembelajaran dengan komputer menjadi salah satu kegiatan yang dapat digunakan untuk menstimulasi kemampuan CT anak. Tujuan penelitian ini adalah untuk menemukan profil kemampuan computational thinking anak usia 5-6 tahun di sebuah PAUD di Kota Surakarta yang menjadi lokasi penelitian ini.

\section{METODE PENELITIAN}

Penelitian ini menggunakan pendekatan kualitatif, Jenis penelitian adalah deskriptif untuk mendeskripsikan dan menggambarkan fenomena yang ada, baik secara alamiah maupun rekayasa manusia dengan memperhatikan karakteristik, kualitas, dan keterkaitan antar kegiatan (Sukmadinata, 2011). Penelitian dilaksanakan di sebuah PAUD Islam Terpadu di Kota Surakarta selama satu tahun (2019-2020). Partisipan penelitian adalah kepala sekolah, wakil kepala sekolah bidang kurikulum, 8 orang guru taman, satu kelas atau 15 anak berusia 5-6 tahun. Teknik pengumpulan data yaitu wawancara, observasi, dan dokumentasi. Observasi dan analisis dokumen dilakukan sebelum proses wawancara.

Observasi dilakukan selama proses pembelajaran dari awal hingga akhir pembelajaran untuk mengamati perilaku anak yang menunjukkan kemampuan computational thinking. Observasi dilaksanakan selama 36 kali dengan langkahlangkah berikut:

1. Ada 4 tema pembelajaran yaitu: Buahbuahan dalam Al-Qur'an, Masjid rumah Allah, Tetanggaku karunia Allah, dan Muamalah dalam Al-Qur'an selama observasi.

2. Pada setiap tema, terdapat 8 kali pertemuan dengan 1 kali pertemuan pada setiap taman. Taman tersebut yaitu taman bahan alam cair, taman sehat, taman ibadah, taman olah tubuh, taman balok, taman main peran, taman multimedia, dan taman pintar.

Sementara proses wawancara bertujuan untuk memperoleh langsung informasi terkait kegiatan selama pembelajaran yang menstimulasi kemampuan CT. Proses wawancara dilaksanakan setelah proses pembelajaran selesai dengan masing-masing partisipan.

Analisis dokumen digunakan untuk melengkapi dan memperkuat bukti penelitian yang berasal dari sumber-sumber yang dapat dipertanggungjawabkan di PAUD yang menjadi lokasi penelitian. Dokumen tersebut antara lain RPPM, RPPH, dokumen penilaian anak, rekaman hasil wawancara, dan fotofoto selama proses observasi. Pedoman observasi, wawancara dan dokumentasi dijabarkan sebagai berikut :

Tabel 1.

Pedoman Observasi

\begin{tabular}{|c|c|}
\hline No & Aspek yang Diamati \\
\hline 1. & $\begin{array}{l}\text { Mampu mengikuti langkah (step by step) } \\
\text { secara urut sesuai perintah yang diberikan. }\end{array}$ \\
\hline 2. & $\begin{array}{l}\text { Memahami kesalahan yang terjadi } \\
\text { pada pengerjaan kegiatan dan mampu } \\
\text { memperbaikinya. }\end{array}$ \\
\hline 3. & $\begin{array}{l}\text { Mampu menuangkan idenya ke dalam sebuah } \\
\text { proyek. }\end{array}$ \\
\hline 4. & $\begin{array}{l}\text { Mampu memecahkan masalah/ tugas menjadi } \\
\text { bagian kecil. }\end{array}$ \\
\hline 5. & $\begin{array}{l}\text { Menunjukkan perilaku anak mampu memahami } \\
\text { simbol/kode yang diberikan. }\end{array}$ \\
\hline 6. & $\begin{array}{l}\text { Menggunakan CPU, monitor, keyboard, dan } \\
\text { mouse sesuai fungsinya. }\end{array}$ \\
\hline 7. & $\begin{array}{l}\text { Mampu mengoperasikan fitur yang ada dalam } \\
\text { aplikasi yang digunakan. }\end{array}$ \\
\hline 8. & $\begin{array}{l}\text { Melakukan pengulangan tindakan dalam } \\
\text { mengerjakan kegiatan yang sama. }\end{array}$ \\
\hline
\end{tabular}


Tabel 2.

Pedoman Wawancara

\section{Sasaran Kepala Sekolah}

1. Bagaimana sejarah berdirinya PAUD ini?

2. Apa model pembelajaran yang di-gunakan di PAUD ini ?

3. Sejak kapan model pembelajaran tersebut digunakan?

4. Apa keunggulan PAUD ini apabila dibandingkan dengan sekolah lain?

5. Bagaimana pendapat kepala sekolah mengenai kemampuan CT ?

6. Menurut kepala sekolah, apakah kemampuan computional thinking dapat dikembangkan di PAUD ini? Bagaimana implementasinya?

Sasaran Wakasek Bidang Kurikulum

1. Apa model pembelajaran yang di-gunakan di PAUD ini?

2. Sejak kapan model pembelajaran ter-sebut digunakan?

3. Adakah ketentuan khusus dalam pemilihan tema dan subtema pada setiap bulannya?

4. Bagaimana proses penentuan materi pembelajaran pada setiap taman?

5. Apakah wakil kepala sekolah bidang kurikulum mengetahui kemampuan CT ? jika me-ngetahui, bagaimana pendapat anda?

6. Apakah memungkinkan apabila kemampuan CT diterapkan di PAUD ini? bila memungkinkan, bagaimana gam-baran penerapannya ?

\section{Sasaran Guru Taman}

1. Bagaimana guru mengetahui terkait adanya kemampuan CT ?

2. Adakah kegiatan yang mengasah kemampuan anak untuk mengikuti rangkaian instruksi yang diberikan pada taman ini ? jika ada, kegiatan apa?

3. Bagaimana perilaku anak dalam menggunakan CPU, monitor, keyboard, dan mouse?

4. Bagaimana penguasaan anak terhadap fitur yang terdapat dalam aplikasi yang digunakan?

5. Adakah kegiatan yang memungkinkan anak untuk memecahkan tugas menjadi bagian kecil ? jika ada, kegiatan apa?

6. Adakah kegiatan yang membuat anak untuk melakukan suatu tindakan secara berulang, sebab akibat, dan prasyarat? jika ada, kegiatan apa?

7. Adakah kegiatan yang memungkinkan anak untuk memahami makna-makna dari suatu simbol ? jika ada, kegiatan apa?

8. Ketika mengerjakan suatu tugas, kemudian anak melakukan kesalahan, apakah anak mampu untuk memperbaiki kesalahan tersebut?
9. Apakah terdapat kegiatan yang menuntut anak untuk menggali ide dan menghasilkan suatu karya sesuai idenya ? jika ada, kegiatan apa ?

10 Apakah memungkinkan apabila ke-mampuan CT diterapkan di PAUD ini ? jika iya bagaimana implementasinya pada taman ini?

Tabel 3.

Pedoman Dokumentasi

\begin{tabular}{cl}
\hline No & \multicolumn{1}{c}{ Informasi yang Diperoleh } \\
\hline 1. & Dokumentasi susunan pembelajaran \\
2. & Dokumentasi hasil penilaian anak \\
3. & Dokumentasi kegiatan pembelajaran \\
\hline
\end{tabular}

Teknik analisis data dilaksanakan melalui pengumpulan data, reduksi data, penyajian data, dan penarikan kesimpulan. Setelah transkrip catatan observasi dan dokumentasi terkumpul, peneliti mengkategorikan data sesuai dengan indikator penelitian yang telah ditentukan. Peneliti juga melakukan proses reduksi untuk data-data yang tidak sesuai dengan indikator yang telah ditentukan.

Setelah data observasi dan dokumentasi sesuai, peneliti melakukan proses wawancara untuk mengonfirmasi kebenaran data dan memperdalam temuan penelitian. Setelah data wawancara terkumpul, dilakukan proses pengkategorian dan reduksi sesuai dengan kedelapan indikator dan membuang data-data yang tidak diperlukan. Setelah ketiga jenis data terkumpul, peneliti melakukan uji validitas memalui triangulasi teknik dan peningkatan ketekunan. Triangulasi teknik dilaksanakan dengan menyandingkan antara hasil observasi, hasil wawancara dengan guru, serta dokumentasi yang didapatkan selama proses penelitian. Hal tersebut dilakukan untuk mendapatkan keselarasan data dari ketiga jenis teknik pengumpulan data.

Peningkatan ketekunan dilaksanakan untuk mengecek kebenaran data pada hasil penelitian. Peneliti melakukan pengamatan secara mendalam dengan data-data yang diperoleh. Peneliti juga meningkatkan pemahaman dengan menambahkan referensi dari berbagai sumber dan hasil yang berkaitan dengan penelitian. Dengan demikian, pengamatan yang dilakukan dapat menghasilkan kepastian data dan keakuratan data secara sistematis.

Setelah data dianggap valid, peneliti melakukan penyajan data dan penarikan kesimpulan untuk menjawab rumusan masalah dan tujuan penelitian. 


\section{HASIL DAN PEMBAHASAN}

\section{HASIL}

Hasil data penelitian menunjukkan bahwa kemampuan computational thinking anak usia 5-6 tahun di PAUD yang menjadi lokasi penelitian berkembang secara beragam pada masing-masing anak sesuai dengan stimulasi yang diberikan oleh guru dan sesuai dengan tingkat pemahaman masingmasing anak. kemampuan-kemampuan tersebut muncul saat kegiatan pembelajaran baik dengan media komputer maupun tanpa komputer. Jabaran dari keberagaman capaian kemampuan tersebut adalah sebagai berikut :

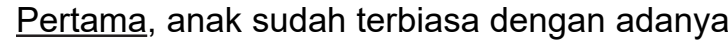
intruksi yang memerlukan beberapa langkah yang diberikan oleh guru. Kedua, anak terlatih untuk berusaha dalam mencari solusi dari permasalahan yang didapatkan. Penemuan solusi tersebut didapatkan baik berdasarkan hasil pemikiran masing-masing anak maupun melalui proses diskusi dengan guru dan atau teman sebaya. Ketiga, anak terlatih untuk mengungkapkan ide baik berupa suatu gagasan, pendapat, atau dalam bentuk karya. Keempat, anak mampu membagi tugas untuk dikerjakan terlebih dahulu dengan atau tanpa bantuan arahan dari guru. Kelima, anak terbiasa dengan ice breaking yang melibatkan penerjemahan kode. Keenam, anak-anak di PAUD sudah mengenal dan terbiasa mengoperasikan komputer dengan berbagai kegiatan yang ada di taman multimedia. Ketujuh, anak mengenal dan mengetahui fungsi dari fitur colour dan shape yang terdapat pada aplikasi power point dan paint. Kedelapan, anak menerapkan solusi ke dalam permasalahan yang sama pada beberapa kegiatan yang memiliki kemiripan dalam penyelesaian.

Selama masa observasi atau 36 kali pertemuan, kedelapan aspek kemampuan CT tidak muncul setiap hari. Aspek-aspek kemampuan CT muncul apabila kegiatan yang dilaksanakan pada pembelajaran menstimulasi aspek tersebut. Dari kedelapan aspek, algoritma merupakan aspek yang paling sering muncul pada setiap kegiatan yang dilaksanakan di taman.

Kemampuan dalam memahami instruksi muncul setiap kali observasi. Kemampuan ini muncul melalui pemberian jadwal kegiatan selama satu hari yang cenderung berbeda setiap harinya. Rangkaian kegiatan setiap harinya adalah baris sesuai kelas, berdoa bersama, melafalkan Asmaul Husna, ice breaking, kegiatan di taman, makan kudapan dan istirahat, kegiatan litaqwa, makan siang, sholat, dan pulang. Kegiatan-kegiatan tersebut diadakan dengan konsep moving atau berpindah tempat pada setiap kegiatan sehingga anak terbiasa untuk menghafalkan rangkaian kegiatan beserta tempat yang akan digunakan.

Rata-rata kegiatan yang dilaksanakan di taman memiliki langkah main berjumlah 3 hingga 7 langkah. Guru akan menjelaskan langkah main tersebut di awal pembelajaran dan meminta anak untuk mengingatnya. Guru juga menggunakan konjungsi pengurutan seperti pertama, kedua, lalu, setelah itu, kemudian, dan lain sebagainya. Hal tersebut membantu anak untuk memahami bahwa terdapat rangkaian urutan yang harus ditempuh. Oleh karena kemampuan ini sangat sering distimulasi, maka semua anak dapat memahami instruksi yang diberikan guru dengan disertai contoh pelaksanaan.

Kemampuan anak untuk memahami dan memperbaiki kesalahan muncul 16 kali selama masa observasi. Pada beberapa kegiatan pembelajaran, guru memberikan kesempatan penuh kepada anak untuk menyelesaikan kegiatan. Sehingga berdasarkan observasi yang dilakukan peneliti, rata-rata anak mengalami kesalahan ketika menyelesaikan tugas namun dapat dengan cepat mengatasi masalah tersebut. Anak-anak mendapatkan solusi dari hasil pemikirannya sendiri, melihat solusi yang dimiliki teman, atau dengan berdiskusi dengan teman. Guru juga akan turun tangan ketika anak meminta bantuan dengan cara membimbing menuju solusi bukan langsung memberikan solusi. Berdasarkan hasil observasi 8 anak dapat memahami kesalahan serta memperbaikinya secara mandiri dan 5 diantaranya membantu teman untuk mencari solusi, 5 anak melalui proses diskusi dengan teman, dan 2 anak belum dapat dan enggan menerima bantuan dan saran dari temannya.

Kemampuan menuangkan ide kedalam berbagai karya muncul sebanyak 16 kali selama masa observasi. Ide anak berupa sebuah gagasan, pendapat, dan dalam bentuk karya. Selama observasi, kemampuan ini muncul ketika anak berada pada kegiatan berkarya seperti membuat pop-up masjid, melukis dengan benang, membuat kolase, mendesain baju, bermain peran, membuat bangunan di taman balok, dll.

Sebelum anak-anak mengeksekusi idenya, guru akan memberikan stimulus untuk memperdalam imajinasi anak. stimulus tersebut berupa kegiatan diskusi, bercerita, melihat gambar atau video yang berhubungan dengan tema pada hari itu. Setelah 
guru memberikan stimulus tersebut, guru memastikan kedalaman ide anak dengan menanyai anak satu persatu terkait imajinasi yang dimiliki. Atau guru akan mengajak anak untuk menggabungkan idenya dengan teman yang lain ketika berada pada kegiatan bermain peran. Hal tersebut dikarenakan pada kegiatan bermain peran, anak harus bermain secara bersama-sama dengan memainkan peran masingmasing sesuai skenario yang telah disusun bersama. Berdasarkan hasil observasi dapat disimpulkan bahwa 7 orang anak aktif dalam mengungkapkan ide dalam kelompok besar maupun kelompok kecil, 4 orang mau meng-ungkapkan pendapat ketika diminta, dan 4 orang idem temannya.

Kemampuan membagi tugas menjadi bagian kecil, muncul 7 kali selama observasi. 4 diantaranya muncul pada kegiatan ditaman balok. Pada taman ini, anak membangun balok pada landasan yang telah ditentukan. Satu landasan berisi dua hingga tiga anak. sebelum menyusun balok menjadi beberapa bangunan, biasanya anak akan membagi sisi landasan untuk diisi bangunan tertentu dan sisi yang lain untuk diisi yang lainnya. Seperti pada tema masjid rumah Allah, anak membagi landasan menjadi 4 bagian yaitu sisi atas, tengah, kiri bawah dan kanan bawah.

Pada sisi atas, anak membangun sebuah masjid berlantai 1 dengan menara disebelah kanan dan kiri bangunan. Pada sisi tengah anak membangun jalan dan jembatan penyebrangan. Sedangkan sisi kiri bawah digunakan untuk lahan parkir dan sisi kanan bawah untuk taman. Anak melakukan perencanaan tata letak bangunan tersebut dengan jalan diskusi.

Selama 4 kali observasi di taman balok, ditemukan bahwa kemampuan membagi tugas anak perempuan lebih menonjol dibanding anak laki-laki. Hal ini ditunjukkan dengan anak perempuan lebih bisa membagi tugas dan menyelesaikan secara satu persatu. Sehingga dalam satu landasan konsep dan tata letak bangunan lebih terlihat memiliki satu kesatuan dan terkonsep. Sedangkan landasan milik anak laki-laki terlihat berdiri secara sendiri-sendiri dan belum menunjukkan adanya satu kesatuan.

Penyebab dari hal di atas adalah belum adanya kemauan dari anak laki-laki untuk berdiskusi dan membagi tugas dalam satu kelompok yang dimiliki. Meskipun guru sudah membagi satu landasan untuk 3 orang dan meminta agar membangun secara bersamasama, anak laki-laki lebih memilih untuk menggaris daerah teritorialnya dan membangun sesuai dengan imajinasi masing-masing anak.

Kemampuan pembagian tugas lainnya muncul pada kegiatan membuat pop-up di taman bahan alam cair. Kegiatan tersebut terbagi menjadi 3 yaitu menggunting, mengelem, dan mewarnai. Sebelumnya, guru telah menyampaikan bahwa anak bebas menentukan kegiatan yang akan dilakukan terlebih dahulu. Guru berpesan kepada anak untuk mengerjakan kegiatan yang sekiranya kosong. Sehingga masing-masing anak memungkinkan untuk memiliki urutan kegaitan yang berbeda tergantung dengan kondisi saat pengerjaan tugas. Berdasarkan pemaparan tersebut dapat disimpulkan bahwa 8 orang anak mampu memecah kan masalah menjadi bagian yang kecil dengan jalan berdiskusi dengan teman sedangkan 7 anak masih enggan untuk melakukannya.

Pemahaman terhadap simbol/kode muncul beberapa kali pada saat observasi. Seperti pemahaman simbol uks, toilet laki-laki dan perempuan, dsb. Namun pada penelitain ini, peneliti berfokus pada kode yang tersusun dalam satu rangkaian. Kegiatan ini muncul sebanyak 2 kali di kegiatan ice breaking yang dilakukan pada kegiatan pembukaan dan 1 kali muncul pada ice breaking di taman pintar.

Pada Ice breaking yang pertama, kode yang digunakan adalah merah (maju satu langkah ke depan), kuning (mundur satu langkah kebelakang, biru (geser ke kanan satu langkah), hijau (geser ke kiri satu langkah). Pada ice braking kedua, kode yang digunakan adalah tap (lompat ke kanan satu kali), tip (lompat ke kiri satu kali), top (melompat ke atas), tup (berjongkok). Pada ice breaking ketiga, kode yang digunakan adalah sab (berdiri tegak), sib (setengah berjongkok), sub (berjongkok sempurna).

Pada setiap awal kegiatan ice breaking ini, guru akan melakukan diskusi dengan anak untuk menentukan kode dan arti kode yang akan digunakan saat itu. Setelah menemukan kesepakatan, guru akan mencoba dengan variasi dua kode terlebih dahulu seperti sab-sib atau tap tup, dan sebagainya. Kemudian anak akan menerjemahkan kode tersebut melalui gerakan yang sesuai dengan arti kode yang diberikan. Setelah berhasil guru menaikkan level kerumitan kode hingga 5 rangkaian variasi seperti tup, tip, tep, tip, tap, dan sebagainya.

Saat observasi dilakukan di hari ke 9 atau saat ice breaking kedua, terdapat satu anak yang terlambat datang sehingga anak tersebut belum mengetahui kesepakan simbol yang digunakan. Anak tersebut kemudian mendengarkan instruksi yang diberikan guru dan gerakan yang ditunjukkan teman-temannya. Setelah melewati dua intruksi, anak dapat memahami kode beserta arti yang diberikan guru. Kemudian anak mengikuti intruksi yang diberikan oleh guru selanjutnya. Sehingga dapat disimpulkan bahwa 15 
anak mampu menerjemahkan kode yang diberi-kan guru meski satu anak datang terlambat.

Anak-anak di PAUD ini sudah terbiasa mengoperasikan komputer sejak berada di KB (Kelompok Bermain). Pembelajaran menggunakan komputer dilaksanakan di taman multimedia. Pada taman ini terdapat 4 komputer yang digunakan oleh anak secara bergantian. Masing-masing komputer menyediakan game berbeda yang nantinya akan dikerjakan oleh anak secara individu dan bergantian. Biasanya, guru menyiapkan game dengan susunan dua komputer menggunakan game yang pengoperasiannya melalui keyboard dan dua komputer menggunakan mouse.

Pada awal pembelajaran, guru akan mengajak anak berkeliling untuk mengetahui cara main dari game-game yang digunakan. Guru akan mengajak anak unuk kembali mengingat-ingat nama dari CPU, Monitor, keyboard, dan mouse. Guru juga menekankan kepada anak untuk tidak memencet tombol-tombol yang ada pada CPU dan monitor. Sehingga anak hanya berkesempatan untuk mengoperasikan keyboard dan mouse. Guru akan memberikan contoh pengerjaan dari game game yang telah disediakan. Setelah guru selesai memberikan contoh, guru akan mempersilahkan anak yang dapat menjawab pertanyaan untuk memilih game yang akan diainkan terlebih dahulu dan seterusnya.

Pada perangkat keras keyboard, tombol yang dikuasai anak adalah tombol huruf, angka, spasi, enter, dan backspase. Tombol-tombol lain yang ada pada keyboard belum dikenalkan oleh guru. Meskipun anak belum hafal tata letak huruf yang ada pada keyboard, namun anak memahami bahwa ketika terdapat instruksi untuk mengetik, maka harus menggunakan keyboard dan memindai huruf satu persatu sebelum mengetik kata dengan menggunakan kedua jari telunjuk.

Pada game yang memerlukan bantuan mouse, anak-anak menggunakan mouse sesuai kebutuhan. Anak-anak lihai dalam menggerakkan kursor ke arah yang dituju. Sangat jarang anak yang justru memutar atau menggerakkan kursor ke sembarang arah tanpa tujuan. Anak juga mampu dalam keterampilan klik mouse, lalu mengarahkan kursor, dan mengklik mouse lagi. Ke-terampilan lain yang dikuasai anak adalah klik mouse, drag, dan klik. Oleh karena pengenalan komputer yang dilakukan sejak KB, maka tidak mengherankan apabila 15 anak mampu mengoperasikan mouse dan keyboard sesuai fungsi. Sedangkan untuk CPU dan monitor, anak belum mendapatkan kesempatan untuk menggunakannya.
Kemampuan mengoperasikan fitur dalam aplikasi muncul 2 kali selama observasi di taman multimedia. Kegiatan pertama yaitu kegiatan menggambar dengan menggunakan aplikasi paint. Pada aplikasi ini, fitur yang digunakan adalah shape yang digunakan untuk membuat bentuk, fitur dengan simbol kaleng cat untuk mewarnai, dan fitur color untuk memilih warna yang akan digunakan. Guru memberikan contoh terlebih dahulu untuk memberikan gambaran kepada anak serta menunjukan fitur-fitur yang dibutuhkan selama proses pengerjaan. Setelah itu anak mengerjakan satu persatu secara bergantian dengan didampingi oleh guru yang bertugas mengarahkan ketika anak mengalami kesulitan.

Kegiatan kedua yaitu menghubungkan gambar dengan aplikasi power point. Pada kegiatan ini, disediakan 4 pasang gambar profesi dan tempat kerjanya yang disusun secara acak dan bersebrangan. Anak diminta untuk menghubungan dengan benar. Fitur yang digunakan adalah shape gambar garis. Guru memberikan contoh terlebih dahulu untuk memberikan gambaran pengerjaan kepada anak. Setelah itu anak mengerjakan satu persatu secara bergantian secara mandiri tanpa dampingan guru. Meskipun pengenalan fitur ini jarang diberikan oleh guru, namun 15 anak mampu mengoperasikan fitur shape, gambar kaleng cat, dan color pada aplikasi paint dan power point.

Kemampuan pengulangan tindakan yang sama, muncul dua kali selama observasi yaitu pada taman olah tubuh. Pengulangan tindakan berupa kegiatan estafet dilakukan dengan perbedan tema dan tingkat kesulitan. Tema pada estafet pertama yaitu buahbuahan dalam Al-Quran. Pada estafet ini anak diminta untuk berlari mengambil gambar buah pisang dan menempelkannya sesuai dengan lambang bilangan pada papan tempel. Pada kegiatan ini, anak-anak mampu me-nyelesaikan sesuai dengan waktu yang telah ditentukan oleh guru.

Kegiatan kedua yaitu estafet urutan sholat. Anak diminta untuk mengambil gambar sesuai urutan shalat dari takbiratul ikhram hingga salam dan menempelkannya pada papan tempel. Pada kegiatan ini terdapat dua anak yang menghabiskan waktu melebihi ketentuan dari guru. Hal tersebut dikarenakan kedua anak tersebut membutuhkan waktu yang lebih lama dalam memilih urutan shalat yang tepat. Pada kemampuan ini, 10 anak mampu mengulangi tindakan dengan waktu kurang dari ketentuan yang telah diberikan. 3 anak menyelesaikan sesuai ketentuan waktu dan dua orang membutuhkan waktu melebihi ketentuan. 
Berdasarkan pemaparan hasil data observasi yang telah di atas, data dapat diringkas untuk memudahkan pemahaman dalam tabel sebagai berikut :

Tabel 1.

Ringkasan Hasil Observasi

\begin{tabular}{|c|c|c|}
\hline $\begin{array}{l}\text { Kemampuan } \\
\text { Computational } \\
\text { Thinking }\end{array}$ & $\begin{array}{l}\text { Pada } \\
\text { obser- } \\
\text { vasi hari } \\
\text { ke }\end{array}$ & Hasil Belajar \\
\hline $\begin{array}{l}\text { Mengikuti lang- } \\
\text { kah secara urut } \\
\text { sesuai perintah } \\
\text { yang diberikan }\end{array}$ & $1-36$ & $\begin{array}{l}15 \text { anak dapat mema- } \\
\text { hami instruksi yang } \\
\text { diberikan guru dengan } \\
\text { disertai contoh. }\end{array}$ \\
\hline
\end{tabular}

M e mah a mi 1, 2, 3, 8, 8 anak dapat memakesalahan dan $9,10,12$, hami ke-salahan serta memperbaiki 15,17 , memperbaikinya senya $\quad 18,19$, cara mandiri dan 5 21,23 , diantaranya membantu 27,28 , teman untuk mencari 30,32 , solusi, 5 anak melalui 34, 35 proses diskusi dengan teman, dan 2 anak belum dapat dan enggan menerima bantuan dan saran dari temannya.

Menuangkan 1, 2, 3, 7 orang anak aktif daide kedalam 8, 9, 10, lam meng-ungkapkan berbagai karya. 12,15 , ide dalam kelompok 17 , 18, besar maupun kelom23, 27, pok kecil, 4 orang mau 28 , 30, meng-ungkapkan pen32, 35 dapat ketika di-minta, dan 4 orang idem temannya.

Membagi tugas $1,8,9,8$ orang anak mampu menjadi bagian 19,21 , memecah kan maskecil. 23 alah menjadi bagian yang kecil dengan jalan berdiskusi dengan teman sedangkan 7 anak masih enggan untuk melakukannya.

Memahami sim- 2, 9,13 15 anak mampu men$\mathrm{bol} / \mathrm{kode}$ yang erjemahkan kode yang diberikan. diberi-kan guru meski satu anak datang terlambat.

Menggunakan 7, 15, 2315 anak mampu menCPU, Monitor, keyboard, dan mouse sesuai fungsinya.

\begin{tabular}{ll}
\hline $\begin{array}{l}\text { Mengoper- } \\
\text { asikan fitur } \\
\text { yangada dalam } \\
\text { aplikasi yang di- } \\
\text { gunakan }\end{array}$ & $\begin{array}{l}15 \text { anak mampu } \\
\text { mengoperasikan fitur } \\
\text { shape, gambar kaleng } \\
\text { cat, dan colorpada ap- } \\
\text { likasi paint dan power } \\
\text { point. }\end{array}$ \\
\hline $\begin{array}{l}\text { Melakukan 2,19 } \\
\text { pengulangan }\end{array}$ & $\begin{array}{l}10 \text { anak mampu men- } \\
\text { gulangi tindakan den- }\end{array}$ \\
tindakan dalam & $\begin{array}{l}\text { gan waktu kurang dari } \\
\text { mengerjakan }\end{array}$ \\
kegiatan yang & $\begin{array}{l}\text { ah diberikan. 3 anak } \\
\text { menyelesaikan sesuai } \\
\text { sama. }\end{array}$ \\
& $\begin{array}{l}\text { ketentuan waktu dan } \\
\text { dua orang membu- } \\
\text { tuhkan waktu melebihi } \\
\text { ketentuan. }\end{array}$ \\
\hline
\end{tabular}

Berdasarkan hasil observasi yang dilakukan, dapat diketahui bahwa kemampuan CT anak ditunjukkan secara beragam. Hal tersebut sesuai dengan stimulasi yang diberikan oleh guru serta intensitas dalam memberikan stimulasi. Seperti pada aspek algoritma yang menunjukkan bahwa semua anak mampu memahami perintah yang diberikan. Hal tersebut dikarenakan guru setiap hari memberikan stimulus sehingga otak anak terbiasa mencerna rangkaian-rangkaian instruksi.

Pada aspek penggunaan perangkat komputer dan pemahaman fitur juga me-nunjukkan bahwa semua anak mampu menguasainya meskipun data observasi hanya menunjukkan 4 kali muncul. Hal tersebut dikarenakan interaksi anata anak dan komputer dalam pembelajaran sudah di-lakukan sejak anak berada di KB. Jadi pada kelompok B sudah sangat akrab dengan komputer meskipun terdapat hal-hal baru yang dikenalkan oleh guru melalui game yang disediakan.

Sedangkan untuk aspek yang lain menunjukkan hasil yang cukup memuaskan dilihat dari banyaknya anak yang mampu menguasai.

Hasil observasi juga diperkuat dengan beberapa dokumentasi sebagai berikut :

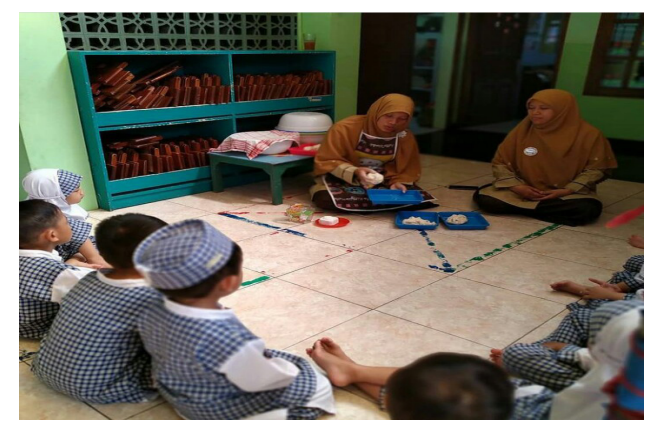

Gambar 1. Guru memberikan penjelasan terkait langkah pembuatan cilok disertai dengan contoh pengerjaan. 


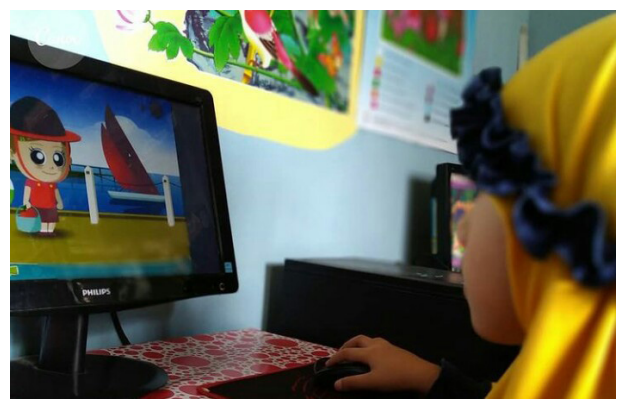

Gambar 2. Anak mengoperasikan komputer secara individu dan bergantian

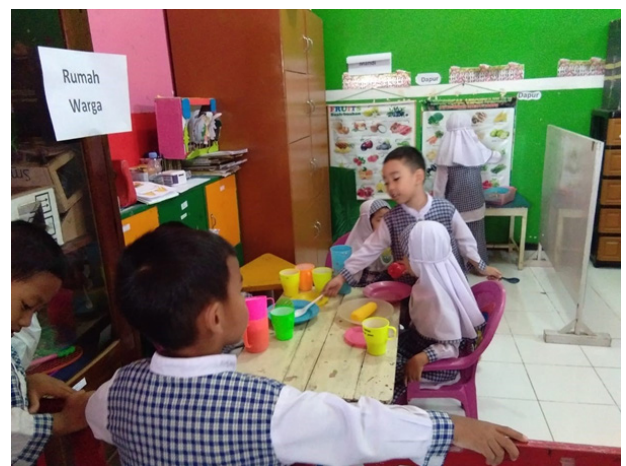

Gambar 3. Anak memiliki kendali penuh dalam penyusunan dialog dan alur cerita pada taman main peran

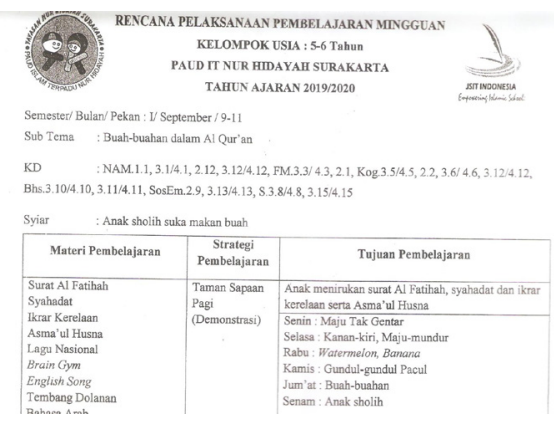

Gambar 4. Bukti RPPM yang menunjukkan ice breaking penerjemahan simbol/kode.

Proses wawancara dilaksanakan setelah pengmpulan data observasi dan dokumetasi selesai. Hal tersebut bertujuan untuk mendapatkan poin-poin penelitian yang akan ditanyakan pada narasumber. Wawancara dilakukan kepada kepala sekolah, wakil kepala sekolah, guru kelas, dan guru taman. Wawancara dilakukan setelah proses pembelajaran selesai atau disela-sela istirahat agar tidak mengganggu proses pembelajaran.

Berdasarkan hasil wawancara menunjukkan bahwa meskipun sebagian besar guru belum mengetahui kemampuan CT, namun kegiatan-kegiatan yang dilaksanakan pada pembelajaran sebagian besar menstimulus kemampuan ini. Pernyataan tersebut sesuai dengan pernyataan wakil kepala sekolah bidang kurikulum sebagai berikut :
"Untuk istilah computational thinking, algoritma, modularitas, hardware, software dan lain sebagainya memang kami belum begitu familiar. Namun pembelajaran di PAUD sudah menerapkan pemikiran-pemikiran atau konsep dari aspek-aspek tersebut. Walaupun memang kami belum memahami bahwa ternyata inilah istilah dari konsep yang selama ini kami berikan."

Kemampuan CT memang tergolong kemampuan yang baru dikenal di Indonesia. Oleh karena itu sangat wajar apabila masih banyak guru yang belum memahami kemampuan ini. Namun demikian, guru sangat terbuka dengan adanya kemampuan baru ini dan antusias untuk mempelajari lebih lanjut. Hal tersebut sesuai dengan pernyataan kepala sekolah sebagai berikut :

"Kami berprinsip bahwa kemajuan dan pembaharuan dunia pendidikan sangat diterima disini. Dengan catatan bahwa akan adanya penyesuaian-penyesuaian sesuai dengan kurikulum yang kami miliki. Apapun peruahan itu, apabila kami rasa baik, maka kami akan mengkaji lebih lanjut terutama ini dalam bidang teknologi."

Hasil kemampuan anak pada aspek-aspek CT juga menunjukkan capaian yang memuaskan. hal ini berdasarkan jumlah anak yang menunjukkan tindakan sesuai indikator rata-rata lebih banyak dibandingkan dengan yang belum menunjukkan tindakan sesuai indikator. Hal tersebut diperkuat dengan pernyataan guru sebagai berikut :

"Alhamdulillah anak-anak itu rata-rata sangat mudah menyerap informasi atau pengetahuan baru yang telah diberikan. Terutama apabila diberikan contoh itu hanya perlu satu kali setelah itu anak jalan sendiri. Jadi tugas kami ya mendampingi tanpa menggurui dan membantu anak untuk menggali ide-ide mereka dengan berbagai cara."

\section{PEMBAHASAN}

Berdasarkan hasil penelitian, profil kemampuan computational thinking anak usia 5-6 tahun, meliputi:

Pertama, Anak-anak mampu mengikuti instruksi sesuai dengan yang diperintahkan oleh guru berupa instruksi satu langkah dan multi-langkah. Hal tersebut sesuai dengan pernyataan (Zhang \& Nouri, 2019) bahwa anak-anak dengan mudah memahami konsep ini karena sering menemukannya dalam kehidupan sehari-hari. Pemberian instruksi sederhana sering ditemui anak dalam percakapan sehari-hari, baik instruksi satu langkah seperti permintaan menutup pintu hingga instruksi multi langkah seperti langkah 
mengerjakan suatu tugas, langkah memakai baju, hingga rangkaian persiapan yang perlu dilakukan sebelum anak berangkat sekolah.

Beberapa anak mungkin mengalami kendala. Namun, hal tersebut tidak begitu menjadi masalah dalam proses penilaian pemahaman algoritma anak. Karena pada algoritma yang ditekankan adalah pemahaman terkait urutan langkah yang logis. Selama anak memahami bahwa terdapat langkah yang harus ditempuh setelah ini, maka dapat dikatakan bahwa anak mulai memahami terkait algoritma.

Peneliti menemukan bahwa terdapat berbagai jenis kegiatan yang dapat menstimulasi kemampuan algoritma anak muncul pada pembelajaran di PAUD ini. Ciri dari kegiatan yang mengasah algoritma adalah terdapat instruksi di dalamnya atau adanya tugas mengurutkan langkah secara logis untuk anak. Contoh dari pemberian tugas yang memerlukan rangkaian pengerjaan adalah kegiatan gosok gigi, menyikat sandal, membuat aneka masakan, melakukan tindakan P3K (prosedur pertolongan untuk orang pingsan, luka bakar, luka teriris, luka lebam), dan game-game pada komputer yang perngerjaannya dilakukan secara runtut.

Kemampuan algoritma juga terasah dengan adanya rangkaian kegiatan atau jadwal kegiatan yang terulang setiap harinya. Contohnya adalah algoritma yang dilakukan anak sebelum menuju taman quran yaitu menuju kamar mandi untuk buang air kecil, berwudhu, mengambil buku litqwa dan air minum, mengambil meja baca, dan berbaris sesuai kelompok. Ada banyak rangkaian algoritma lainnya yang dijalankan anak setiap harinya. Hal ini menjadikan anak terbiasa melakukan tindakan-tindakan secara teratur dan tersistem.

Kegiatan lain yang dapat menstimulasi algoritma anak adalah dengan meminta mengurutkan suatu langkah atau peristiwa. Seperti kegiatan mengurutkan urutan shalat, mengurutkan urutan wudhu, mengurutkan huruf hijaiyah, mengurutkan lambang angka arab, dan lain-lain. Hal tersebut sesuai dengan pernyataan Papadakis, Kalogiannakis, \& Zaranis (2016) yang menyatakan bahwa anak dapat diminta untuk menyebutkan tindakan yang sesuai dengan instruksi dan meng-klasifikasikan peristiwa dalam urutan logis.

Pada akhir sesi taman main peran, guru meminta anak untuk menceritakan alur cerita yang telah dimainkan anak. Pada kegiatan recalling di berbagai taman yang disediakan rata-rata guru meminta anak memaparkan rangkaian kegiatan hari itu dan tata cara bermainnya. Saat anak-anak berusia
5 tahun, mereka dapat mengikuti instruksi multilangkah dan menceritakan kembali kisah-kisah yang mereka lalui dalam urutan yang benar (Rhode Island Departement of Education (RIDE), 2013).

Kedua, kemampuan mengetahui dan mampu memberikan solusi terhadap suatu masalah. Ketika menyusun sebuah proses penyelesaian masalah, terkadang terdapat beberapa kesalahan yang muncul sehingga menghambat proses atau justru menimbulkan permasalahan baru. Anak mencoba berbagai kemungkinan untuk menyelesaikan masalah secara mandiri. Bukti lain menunjukkan bahwa beberapa anak membantu memberikan solusi untuk temannya ketika terdapat suatu kesalahan dalam penyelesaian masalah. Solusi-solusi tersebut seperti mengubah urutan langkah, meruntut kembali langkahlangkah yang telah ditempuh, atau mencoba-coba untuk memperbaiki permasalahan dalam langkah penyelesaian (CSTA, 2017).

Proses debugging paling sering muncul pada taman balok dan taman main peran. Anakanak terbiasa mengubah susunan serta tata letak balok untuk mencapai bangunan yang diharapkan dan mengubah dialog atau skenario cerita. Guru memberikan ke-sempatan penuh kepada anak untuk mencoba memperbaiki kejanggalan-kejanggalan yang ditemui selama pengerjaan karya. Biasanya, ketika anak sudah mencoba dan tidak me-nemukan solusi, anak akan meminta bantuan dari guru. Sangat disarankan untuk guru mem-bimbing dalam proses perolehan solusi, bukan mengambil alih pekerjaan yang dimiliki anak.

Ketiga, mengungkapkan ide ke dalam berbagai karya. Berbagai jenis ide di-ungkapkan anak selama kegiatan di berbagai taman. Jenis ide tersebut berupa karya seni dua dimensi, karya seni tiga dimensi, maupun karya dalam seni peran. Karya dua dimensi anak berupa hasil mewarnai, melukis, dan menempel. Karya tiga dimensi berupa bangunan yang dibentuk pada taman balok.

Sedangkan karya dalam seni peran berupa hasil dialog, alur cerita serta akting yang ditunjukkan anak pada taman peran. Proses desain tidak serta merta muncul begitu saja. Anak melewati beberapa langkah sebelum menuju proses pengkaryaan. Be-berapa langkah tersebut yaitu bertanya, mem-bayangkan, merencanakan, membuat, meng-uji, meningkatkan dan berbagi (Strawhacker \& Bers, 2018).

Pada awal sesi di pembelajaran taman, guru menstimulus ide anak dengan mengajak diskusi terkait tema pada hari itu. Pada proses diskusi muncul kegiatan bertanya, mem-bayangkan, dan 
merencanakan ide-ide yang dimiliki anak. Guru juga membawa gambar-gambar dan cerita untuk membantu anak dalam proses berimajinasi atau mem-bayangkan. Ketika proses eksekusi ide, guru memberikan kebebasan penuh kepada anak untuk menuangkan ide. Pada proses ini anak juga mengalami proses uji coba dan peningkatan kualitas terkait karya yang dikerjakan. Pada akhir sesi, guru akan meminta anak untuk menceritakan maksud dari karya yang telah dibuat.

Keempat, mampu membagi tugas menjadi bagian-bagian kecil. Pada ke-mampuan ini anak belajar bahwa per-masalahan yang rumit tetap dapat di-selesaikan apabila diuraikan menjadi be-berapa bagian. Akan lebih baik apabila pe-nyelesaian masalah dilakukan satu persatu. Sehingga mempermudah dalam pengelolaan masalah dan mempermudah dalam meng-analisis masalah menjadi lebih rinci (Strawhacker \& Bers, 2018).

Stimulasi modularitas sederhana juga dapat diberikan dengan mengajak anak untuk menguraikan suatu benda menjadi bagian-bagian kecil. Untuk membantu pemahaman modularitas, kita bisa mengajak anak untuk membagi suatu benda seperti ice cream pisang yang terdiri dari mangkuk, ice cream coklat, ice cream vanilla, ice cream strawberry, dan pisang (Charismiadji \& Yen, 2020).

Kelima, memahami makna dari kode yang didapatkan. Contoh kegiatannya adalah ice breaking sab-sib-sub. Anak dapat di-ibaratkan sebagai robot atau komputer. Kode sab-sib-sub dapat diibaratkan sebagai bahasa pemrograman. Guru dapat diibaratkan sebagai manusia yang memberikan perintah kepada komputer. Variasi dari susunan sab sib sub adalah algoritma. Sedangkan sab yang berarti maju satu langkah adalah representasi. Anak-anak belajar menerjemahkan kode ke dalam sebuah tindakan melalui kegiatan ini.

Bukti tersebut senada dengan CSTA, (2017) yaitu anak dapat menggunakan jempol keatas atau kebawah untuk merepresen-tasikan ya atau tidak, menggunakan panah yang disusun secara berurutan untuk me-representasikan petunjuk arah, atau memberikan kode berupa angka, gambar, atau sim-bol lainnya untuk merepresentasikan kalimat atau kata. Hal ini mengajarkan kepada anak bahwa suatu kata atau perintah dapat direpresentasikan dengan bentuk lain seperti simbol atau gambar.

Anak-anak yang sudah terbiasa dengan pemberian ice breaking sejenis mampu mengikuti intruksi dengan mudah. Anak akan menunjukkan rangkaian tindakan hasil dari menerjemahkan kode yang diberikan oleh guru. Anak memerlukan perhatian penuh dan responsif selama proses belajar pengkodean (Zhang \& Nouri, 2019). Perlu ditekankan bahwa meski code atau coding diartikan sebagai bahasa yang dapat dipahami komputer, tetapi dalam mengajarkannya tidak harus menggunakan perangkat komputer. seperti yang diungkapkan Hasbi dkk., (2020) bahwa pembelajaran coding dapat dilakukan baik dengan komputer, tanpa komputer maupun dengan kombinasi keduanya.

Keenam, mengetahui nama dan cara mengoperasikan mouse dan keyboard secara sederhana. Anak juga dapat menggunakan mouse, keyboard, CPU, dan monitor sesuai fungsinya. Anakanak yang sebelumnya tidak pernah berinteraksi dengan komputer atau yang sejenis memungkinkan untuk me-nunjukkan perilaku memukul, memencet asal, atau memperlakukan perangkat komputer seperti benda lain (CSTA, 2017). Pada tahun-tahun sebelumnya, penggunaan teknologi untuk menunjang pembelajaran menjadi perdebatan yang sengit, namun saat ini pembelajaran dengan teknologi terutama komputer sudah dipertimbangkan bahkan pada pendidikan awal prasekolah (Papadakis dkk., 2016).

Komputer pada taman multimedia berjumlah 4 unit sedangkan anak perkelas rata-rata berjumlah 10 anak. 4 komputer tersebut tersetting dengan game-game yang berbeda. Sehingga pengoperasian komputer dilaksanakan secara individu dengan bergantian. Setiap awal pembelajaran guru selalu mengenalkan CPU, monitor, mouse dan keyboard. Hal tersebut membantu anak untuk dapat mengidentifikasi dan mengetahui fungsi dari perangkat tersebut (CSTA, 2017).

Anak sudah mengetahui fungsi dan cara kerja dari mouse dan keyboard. Selama pembelajaran anak selalu bersinggungan dekat dengan kedua perangkat tersebut. Hal ini mengakibatkan anak lebih mengenal karakteristik dan cara kerja dari kedua perangkat tersebut dibandingkan dua lainnya. Semakin anak sering berinteraksi, maka anak akan semakin memahami fungsi dan cara kerja dari perangkat yang digunakan (Burke \& Kafai, 2012). Sedangkan kedua perangkat lain, biasanya anak tidak akan menyentuh atau mencoba mengutak-atiknya.

Ketujuh, mengoperasikan fitur shape dan colour pada aplikasi paint dan power point. Anak-anak mendapatkan kesempatan untuk mengeksplore fitur shape dan colour pada kegiatan menggambar dengan paint. Anak mengetahui letak dari kedua fitur tersebut. Aplikasi yang digunakan pada saat pembelajaran sudah dalam keadaan terbuka. Sehingga anak tidak 
mendapatkan ke-sempatan untuk mengoperasikan aplikasi sejak awal. Selama ini anak hanya mengenal fitur shape dan colour pada aplikasi power point dan paint.

Computer Science Teachers Association (2017) mengungkapkan bahwa setidaknya anak harus dapat mengoperasikan komputer dan mengetahui fiturfitur yang tersedia seperti anak paham bahwa untuk menggambar, maka harus menggunakan aplikasi paint. Minimnya jumlah komputer menjadi faktor penyebab pengoperasian komputer dilakukan secara bergantian. Hal tersebut juga mengakibatkan belum adanya kesempatan anak untuk mengeksplorasi perangkat dan aplikasi pada komputer. Akan lebih baik jika satu komputer digunakan untuk satu anak. Sehingga anak mendapatkan kesempatan untuk lebih mengeksplorasi perangkat komputer seperti menghidupkan komputer dan membuka fitur komputer sejak awal.

Kedelapan, mampu mengulang suatu urutan tindakan yang sama untuk menyelesaikan suatu permasalahan. Anak menunjukkan kemampuan dalam mengulang suatu urutan tindakan yang sama untuk menyelesaikan suatu permasalahan pada beberapa kegiatan yang disediakan di taman. Semakin banyak atau semakin sering perilaku tersebut diulang, maka anak akan terbiasa dengan rangkaian tindakan tersebut sehingga waktu yang diperlukan untuk menyelesaikan masalah semakin singkat (Inggriani, 2018).

Satu kegiatan memungkinkan untuk menstimulasi lebih dari satu hingga keseluruhan aspek CT. Hal tersebut sesuai dengan penelitian (Ching dkk., 2018) yang meneliti berbagai alat dan kegiatan yang dapat digunakan untuk menstimulasi kemampuan CT. Hasil penelitian menunjukkan bahwa satu alat atau kegiatan dapat digunakan untuk mengembangkan lebih dari dua aspek CT. baik dengan proyek sederhana hingga proyek dengan tingkat kesulitan yang tinggi. Banyak sedikitnya aspek yang terstimulasi tergantung kepada pemilihan dan pertimbangan guru dalam memberikan kegiatan-kegiatan kepada anak.

Kebijakan Kementerian Pendidikan dan Kebudayaan terkait dengan kebijakan GLN (Gerakan Literasi Nasional) yang mencakup kemampuan literasi dasar salah satunya adalah literasi teknologi (Nasrullah dkk., 2017). Kemampuan literasi teknologi ini butuh dikembangkan sejak dini untuk menghadapi tantangan masa depan yaitu era 4.0 di mana perkembangan teknologi secara global sangat pesat. Begitu juga untuk anak usia dini, pengenalan segala bentuk teknologi di-butuhkan agar anak-anak terampil meng-gunakan teknologi sesuai dengan fungsinya. Salah satu cara menstimulasi kemampuan literasi teknologi pada anak usia dini adalah dengan kegiatan pembelajaran. Oleh karena itu, guru anak usia dini harus mampu memahami kemampuan CT anak agar dapat memberikan stimulasi yang tepat, sehingga hasil penelitian terkait dengan kemampuan CT anak usia dini ini dapat menjadi salah satu rujukan dalam menstimulasi kemampuan teknologi anak usia dini.

\section{PENUTUP}

\section{Kesimpulan}

Berdasarkan hasil penelitian dan pembahasan di atas, dapat disimpulkan bahwa terdapat keberagaman capaian kemampuan computational thinking anak usia 5-6 tahun. Kemampuan computational thinking pada anak antara lain : mampu mengikuti instruksi yang diberikan oleh guru, mampu memahami kesalahan dan memperbaikinya secara mandiri maupun dengan jalan diskusi dengan teman, mampu mengungkapkan ide dalam berbagai karya, mampu membagi tugas menjadi bagian-bagian kecil, mampu menerjemahkan kode yang diberikan guru melalui rangkaian tindakan, mampu memahami dan mengoperasikan mouse dan keyboard sesuai fungsinya, mampu menguasai fitur shape, color, dan gambar kaleng cat pada aplikasi paint dan power point, serta mampu mengulangi tindakan dalam kegiatan yang memiliki karakteristik yang sama.

\section{Saran}

Berdasarkan temuan tersebut, kemampuan computational thinking dapat dikembangkan baik dengan atau tanpa alat komputer atau sejenis. Oleh karena itu, disarankan kepada guru untuk memberikan satu kegiatan yang dapat menstimulasi lebih dari satu aspek computational thinking. Dan agar guru tetap berperan sebagai fasilitator dan provokator agar kemampuan compu-tational thinking anak berkembang optimal.

Disarankan kepada anak agar tetap diberikan kesempatan untuk berinteraksi dengan komputer terlebih mengoperasikan komputer secara penuh. Dan anak agar tetap diberikan berbagai kegiatan yang dapat menstimulus kemampuan computational thinking.

Disarankan kepada sekolah untuk mempertimbangkan kemampuan compu-tational thinking kedalam kurikulum. Hal ini disebabkan semakin 
berkembangnya tekno-logi dengan sangat pesat, sehingga diyakini oleh peneliti bahwa kemampuan ini akan sangat dibutuhkan dimasa mendatang.

Penelitian terkait computational thinking dengan berbagai topik dan prespektif disarankan untuk terus diupayakan terutama di Indonesia. Peneliti diharapkan dapat menggali dan mengkaji lebih dalam mengenai ke-mampuan computational thinking per aspek serta kegiatan yang mampu menstimulus kemampuan computational thinking untuk anak. Dengan begitu akan lebih banyak referensi terkait kemampuan computational thinking terutama untuk anak usia dini.

\section{DAFTAR PUSTAKA}

Beaty, J.J. (2013). Observasi Perkembangan Anak Usia Dini. Terjemahan Anwar. Jakarta: Kencana Prenadamedia Group.

Bers, M.U, Gonzalez, C. G., \& Torres, M. B. A. (2019). Computers \& Education Coding as a playground: Promoting positive learning experiences in childhood classrooms. Computers \& Education, 138 (3), 130-145. DOI: 10.1016/j. compedu.2019.04.013

Bers, M. U. (2018). Coding and Computational Thinking in Early Childhood : The Impact of Scratch Jr in Europe. European Journal of STEAM Education, 3 (3), 1-13. DOI:10.20897/ejsteme/3868

Bocconi, S., Chioccariello, A., Dettori, G., Ferrari, A., \& Engelhardt, K. (2016). Developing Computational Thinking in Compulsory Education; Implications for policy and practice. In Panagiotis, K \& Yves, P. (Eds.), JRC Publications Repository. Luxembourg: Publications Office of the European Union. DOI: 10.2791/792158

Budiansyah, A. (September 2020). Nadiem Usung Computational Thinking Jadi Kurikulum, Apa itu ? cnbcindonesia.com. Retrieved from https://www. cnbcindonesia.com/tech/20200218151009-37138726/nadiem-usung-computational-thinkingjadi-kurikulum-apa-itu

Burke, Q., \& Kafai, Y. B. (2012). The Writers' Workshop for Youth Programmers: Digital Storytelling with scratch in Middle Shool Classrooms. In Proceedings of the 43rd ACM Technical Symposium on Computer Science Education (pp. 433-438). DOI:10.1145/2157136.2157264

Charismiadji, I., \& Yen, C. H. (2020). Computational Thinking for Preschoolers. Retrieved from https://youtu.be/2iQCNFqe5Rs, accesed on October 9, 2020,

Ching, Y.-H., Hsu, Y.-C., \& Baldwin, S. (2018). Developing Computational Thinking with Educational Technologies for Young Learners. Tech Trends, 563-573. DOI: 10.1007/s11528018-0292-7

Csizmadia, A., Curzon, P., Dorling, M., Humphreys,
S., Ng, T., Selby, C., \& Woollard, J. (2015). Computational thinking - a guide for teachers.

CSTA. (2017). Standards Task Force [interim] CSTA K-12 Computer Science Standards. Retrieved from http://c.ymedn.com/sites/ www.esteachers.org/resource/resmgr/Docs/ Standards/CSTA_K-12_CSS.pdf

Depdiknas. (2014). Peraturan Menteri Pendidikan dan Kebudayaan Republik Indonesia Nomor 137 Tahun 2014 Tentang Standar Nasional Pendidikan Anak Usia Dini. Jakarta: Depdikbud.

Ehsan, H., \& Cardella, M. E. (2017, June), Capturing the Computational Thinking of Families with Young Children in Out-of-School Environments Paper presented at 2017 ASEE Annual Conference \& Exposition, Columbus, Ohio. DOI: 10.18260/12--28010

Ehsan, H., \& Dandridge, T., \& Yeter, I. H., \& Cardella, M. E. (2018, June), K-2 Students' Computational Thinking Engagement in Formal and Informal Learning Settings: A Case Study (Fundamental) Paper presented at 2018 ASEE Annual Conference \& Exposition, Salt Lake City, Utah. DOI: 10.18260/1-2--30743

Hasbi, M., Nugraha, A., Mumpuni, N. D., Mudarwan, Warsito, I. H., Koesomawardani, L., \& Widiyawati, E. (2020). Konsep Pembelajaran Coding serta Peran PTK, Orang Tua, Mitra dan Komunitas dalam Penerapan Pembelajaran Coding di Satuan PAUD. Jakarta: Direktorat Pendidikan Anak Usia Dini Direktorat Jenderal Pendidikan Anak Usia Dini, Pendidikan Dasar, Pendidikan Menengah Kementerian Pendidikan dan Kebudayaan.

Liem Inggriani. (2018). Inggriani Liem (Bu Inge) Computational Thinking-BukaTalks. Retrieved October 9, 2020, from https://youtu. be/_6D0ks7wvtl

Nasrullah, R., Aditya, W., Satya, T. I., Nento, M. N., Hanifah, N., Miftahussururi, \& Akbari, Q. S. (2017). Materi Pendukung Gerakan Literasi Digital. Retrieved December 13, 2020, from www.gln.kemendikbud.go.id 
Papadakis, S. J., Kalogiannakis, M., \& Zaranis, N. (2016). Developing fundamental programming concepts and computational thinking with ScratchJr in preschool education: A case study Developing fundamental programming concepts and computational thinking with ScratchJr in preschool education : a case study. International Journal of Mobile Learning and Organisation, 10(3), 187-202. DOI: 10.1504/ IJMLO.2016.077867

Relkin, E. (2018). Assessing Young Children's Computational Thinking Abilities. Thesis. Tufts University.Retrieved from https://dl.tufts.edu/ pdfviewer/vd66wb362/b2774686p

Rhode Island Departement of Education (RIDE). (2013). Rhode Island Early Learning and Development Standards. Retrieved from http://www.ride.ri.gov//InstructionAssesment/ E a r I y C h i I d h o od Ed u c a t i on / EarlyLearningandDevelopmentStandards. aspx\#1669797-literacy-1

Rose, S. P., Habgood, J. M. P., \& Jay, T. (2017). An Exploration of the Role of Visual Programming Tools in the Development of Young Children's Computational Thinking. The Electronic Journal of E-Learning, 15 (4), 297-309. Retrieved from https://files.eric.ed.gov/fulltext/EJ1154629.pdf

Strawhacker, A., \& Bers, M. U. (2018). Promoting Positive Technological Development in a Kindergarten Makerspace : A Qualitative Case Study. European Journal of STEAM Education, 3 (3), 1-21. DOI: 10.20897/ejsteme/3869

Sukmadinata, N. S. (2011). Landasan Psikologi Proses Pendidikan. Bandung: Remaja Rosdakarya.

Sullivan, A., Bers, M. U., \& Mihm, C. (2017). Imagining, Playing, \& Coding with KIBO: Using KIBO Robotics to Foster Computational Thinking in Young Children. In In the proceedings of the International Conference on Computational Thinking, 2017. Wanchai, Hongkong.

Suprapto, Yuwono, K. T., Sukardiyono, T., \& Dewanto, A. (2008). Bahasa Pemrograman. Jakarta: Direktorat Jendral Manajemen Pendidikan Dasar dan Menengah Departemen Pendidikan Nasional.

Zhang, L., \& Nouri, J. (2019). Computers \& Education A systematic review of learning computational thinking through Scratch in K-9. Computers \& Education, 141, 1-25. DOI: 10.1016/j. compedu.2019.103607 
Profil Kemampuan Computational...

96 VISI : Jurnal IImiah PTK PNF - Vol. 16 No. 1, Juni 2021 